\title{
A numerical simulation study of $\mathrm{CO}_{2}$ injection for enhancing hydrocarbon recovery and sequestration in liquid-rich shales
}

\author{
Sumeer Kalra ${ }^{1}$ Wei $\operatorname{Tian}^{2} \cdot$ Xingru $\mathrm{Wu}^{2}$
}

Received: 8 June 2017/Published online: 2 November 2017

(c) The Author(s) 2017. This article is an open access publication

\begin{abstract}
Less than 10\% of oil is usually recovered from liquid-rich shales and this leaves much room for improvement, while water injection into shale formation is virtually impossible because of the extremely low permeability of the formation matrix. Injecting carbon dioxide $\left(\mathrm{CO}_{2}\right)$ into oil shale formations can potentially improve oil recovery. Furthermore, the large surface area in organicrich shale could permanently store $\mathrm{CO}_{2}$ without jeopardizing the formation integrity. This work is a mechanism study of evaluating the effectiveness of $\mathrm{CO}_{2}$-enhanced oil shale recovery and shale formation $\mathrm{CO}_{2}$ sequestration capacity using numerical simulation. Petrophysical and fluid properties similar to the Bakken Formation are used to set up the base model for simulation. Result shows that the $\mathrm{CO}_{2}$ injection could increase the oil recovery factor from $7.4 \%$ to $53 \%$. In addition, petrophysical characteristics such as in situ stress changes and presence of a natural fracture network in the shale formation are proven to have impacts on subsurface $\mathrm{CO}_{2}$ flow. A response surface modeling approach was applied to investigate the interaction between parameters and generate a proxy model for optimizing oil recovery and $\mathrm{CO}_{2}$ injectivity.
\end{abstract}

Wei Tian

wei.tian@ou.edu

1 Warwick Energy Group, 900 W Wilshire Blvd, Oklahoma City, OK 73116, USA

2 University of Oklahoma, 100 E Boyd St. Sec 1210, Norman, OK 73019-1003, USA

Edited by Yan-Hua Sun
Keywords $\mathrm{CO}_{2} \mathrm{EOR}$ - Tight formations - Experimental design - Response surface modeling - Recovery of shale liquid $\cdot \mathrm{CO}_{2}$ sequestration

\section{Introduction}

An unconventional reservoir is a hydrocarbon resource that could not be economically recovered without stimulation because of its extreme low permeability. Even with current stimulation and completion technologies, many fields are expected to produce less than $10 \%$ of initial oil in place. $\mathrm{CO}_{2}$-enhanced oil recovery (EOR) for liquid-rich unconventional reservoirs has been investigated through core flooding (Wang et al. 2017) and field 'huff-n-puff' pilot tests (Hoffman and John 2016). Our literature survey shows that field applications of enhanced oil recovery (EOR) for unconventional oil reservoirs are limited.

The rising level of $\mathrm{CO}_{2}$ in the atmosphere has caused concerns about temperature increases. Carbon capture and storage (CCS) in geological formations deep beneath the surface is an effective approach to reduce $\mathrm{CO}_{2}$ level in the atmosphere (Sorensen et al. 2009; Shen et al. 2015). Geological properties of the prospective $\mathrm{CO}_{2}$ storage formations are analogous to the ones in oil- and gas-producing fields. It signifies the necessary geological conditions that support hydrocarbon accumulation are also conducive for $\mathrm{CO}_{2}$ storage.

$\mathrm{CO}_{2}$ injection and displacement processes are significantly different from each other in tight/shale formations as flow through fractures dominates $\mathrm{CO}_{2}$ displacement. For tight formations, the injected $\mathrm{CO}_{2}$ flows through hydraulic fractures first and then migrates into the rock matrix to swell and displace in-depth oil. In the displacement 
process, $\mathrm{CO}_{2}$ in the reservoir condition behaves as a super critical fluid, which has the viscosity of a gas and liquidlike density. Figure 1 shows the volume change of $\mathrm{CO}_{2}$ with respect to depth. The $\mathrm{CO}_{2}$ property calculation is based on IUPAC correlations (Augus et al. 1973). It is valid from 220 to $1100 \mathrm{~K}$, and the maximum pressure is 1000 bars below $700 \mathrm{~K}, 600$ bars from 700 to $1100 \mathrm{~K}$.

\section{A study of the mechanism of $\mathrm{CO}_{2}$ injection in liquid shale reservoirs}

A compositional model was set up to study $\mathrm{CO}_{2}$ injection and migration in a synthetic liquid shale reservoir for EOR and $\mathrm{CO}_{2}$ sequestration. To focus on the flow mechanisms of $\mathrm{CO}_{2}$ inside the reservoir, a zone of study $(\mathrm{ZoS})$ was created with one injector and one producer. Both wells were horizontal wells within the $12.2 \mathrm{~m}$ of pay zone and had a lateral length of $122 \mathrm{~m}$ each, located in the middle of the pay zone. The laterals of the two wells were parallel and $304.8 \mathrm{~m}$ apart, with fracture perforations in opposite directions, as shown in Fig. 2. We assumed that the flow pattern between each hydraulic fracture pair is similar to the others. Therefore, considering such symmetry, we only included one hydraulic fracture for each well in the ZoS to simplify the simulation (Fig. 2).

Table 1 summarizes the Middle Bakken reservoir properties from the literature, and the averaged values were implemented in our reservoir model. Table 2 gives the reservoir grid dimensions used in the base model and the volume estimated from the simulated reservoir. The gridding of $\mathrm{ZoS}$ is shown in Fig. 2. Grid blocks along the $Y$ and $Z$-directions had equal dimension of 12.2 and $1.22 \mathrm{~m}$, respectively. The grid blocks in the $X$-direction consist of

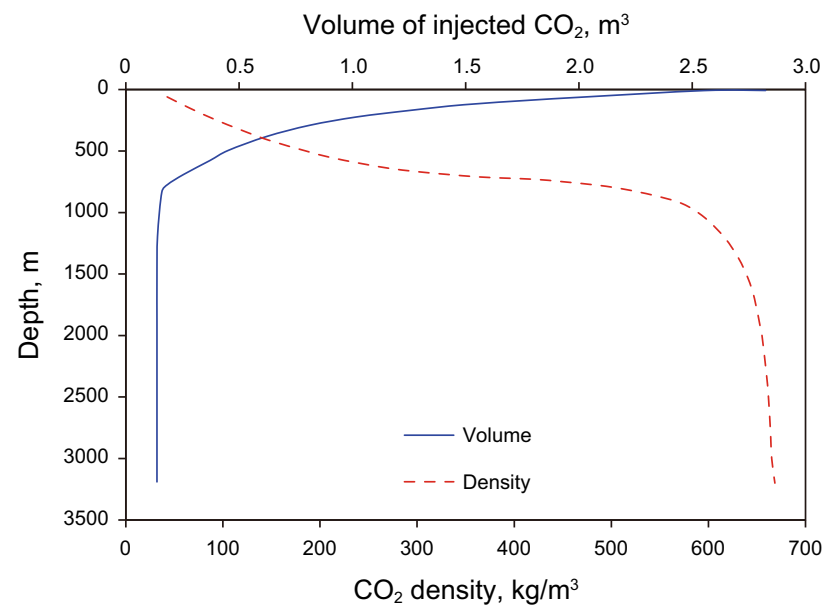

Fig. 1 Volume and density changes with depth for $\mathrm{CO}_{2}$ by considering a geopressure gradient of $9794 \mathrm{~Pa} / \mathrm{m}$ and geothermal gradient of $0.027 \mathrm{~K} / \mathrm{m}$ for a volume of $2.83 \mathrm{~m}^{3}$ of $\mathrm{CO}_{2}$ at surface conditions (Kalra and Wu 2014) local grid refinement near hydraulic fractures. Each hydraulic fracture had a grid dimension of $0.0089 \mathrm{~m}$ as width in the $X$-direction, with logarithmically increasing grid size toward the center to avoid convergence issues. The half-length and height of the injector hydraulic fracture were assumed to be $122 \mathrm{~m}$ in the $Y$-direction and $12.2 \mathrm{~m}$ in the Z-direction, respectively. The injector hydraulic fracture had an enhanced permeability of $2.5 \mathrm{E}-13 \mathrm{~m}^{2}$. The hydraulic fracture connected to the producer at the other side had the same fracture dimensions as the injector fracture but a different fracture permeability of $6.9 \mathrm{E}-14 \mathrm{~m}^{2}$. The hydraulic fracture properties defined in the reservoir model are summarized in Table 3. Matrix grid blocks have permeability of $4.9 \mathrm{E}-18 \mathrm{~m}^{2}$.

The oil from the Middle Bakken Formation is light crude with an average density of $42^{\circ}$ API. The fluid characterization in our model was based on the Nojabaei et al. (2013) study, and the input parameters for the phase behavior study are shown in Tables 4 and 5. The modified Pederson correlation was applied to estimate the viscosity of the reservoir fluid. The calculated bubble point pressure for the fluid was about $1.9 \mathrm{E}+07 \mathrm{~Pa}$. The $\mathrm{CO}_{2}$ flooding is a miscible flooding.

Two separate sets of relative permeability curves were used in this study. One defined the matrix, and the other was for hydraulic fractures. The initial water saturation is 0.30 . The relative permeability curves closely matched the curves obtained by history matching for the Elm Coulee field in North Dakota (Shoaib and Hoffman 2009).

Continuous injection of pure $\mathrm{CO}_{2}$ was modeled. The simulation time was 30 years, starting from January 1, 2010, with an injection bottom-hole pressure of $6.9 \mathrm{E}+07 \mathrm{~Pa}$, which was below the formation fracturing pressure of from $7.6 \mathrm{E}+07$ to $7.9 \mathrm{E}+09 \mathrm{~Pa}$ observed for Middle Bakken Formation. The injection and production constraints are summarized in Table 6 .

\section{Oil shale/tight reservoir characteristics}

To accurately simulate flow in a tight formation with ultralow permeability, a complex fracture network is a crucial part of model. In our study model, hydraulic fractures and natural fractures were explicitly created for simulation.

\subsection{Reservoir heterogeneity modeling}

Reservoir heterogeneity depends on formation lithology, depositional environment and fracture development due to stress changes. Studies of the lithology and depositional environment of the Parshall field in North Dakota showed that the Middle Bakken Formation could be divided into eight different litho-facies with depth, as observed in 


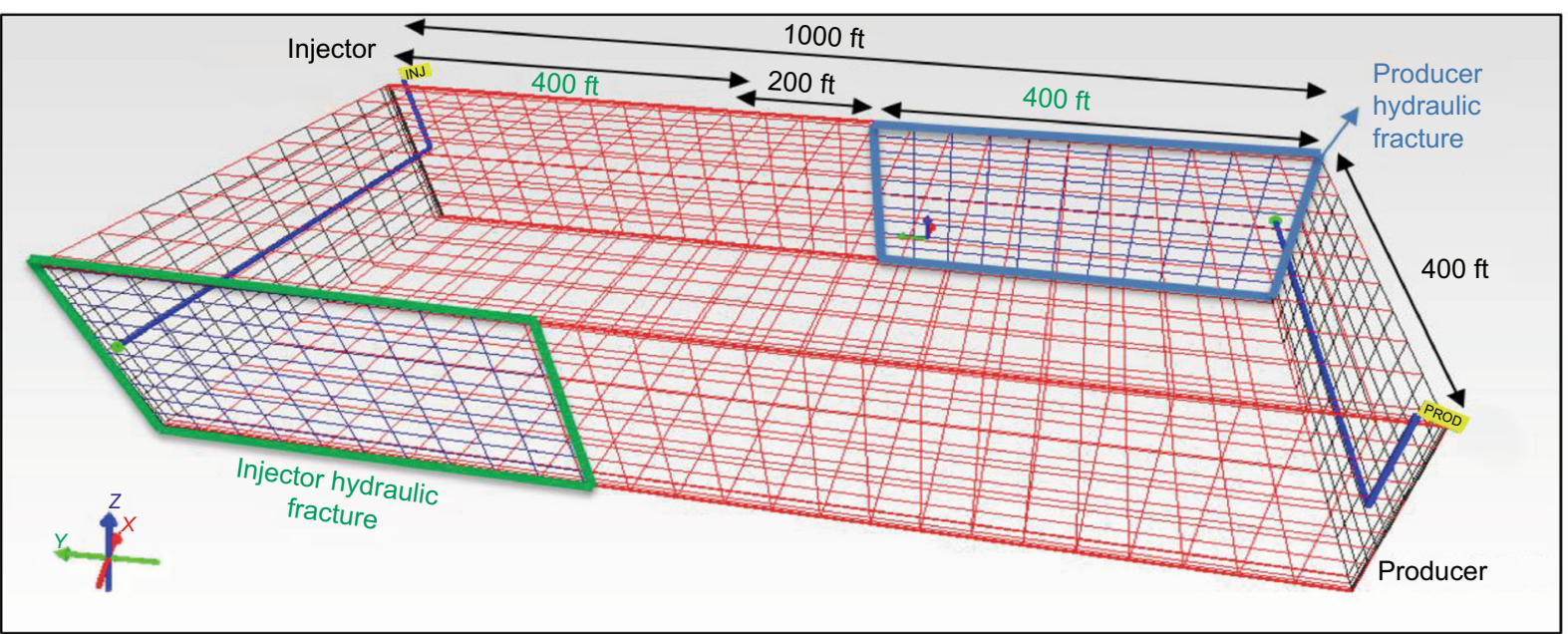

Fig. $2 X-Y$ cross section of the base reservoir model showing the injection and production wells and hydraulic fracture (i.e., zone of study). Blue lines represent the horizontal wellbores

Table 1 Range and average reservoir properties used to build the base model

\begin{tabular}{|c|c|c|c|c|}
\hline \multirow[t]{2}{*}{ Parameter } & \multicolumn{2}{|l|}{ Range } & \multirow[t]{2}{*}{ Average } & \multirow[t]{2}{*}{ Reference } \\
\hline & Min. & Max. & & \\
\hline Reference depth, m & 2896 & 3505 & 3200 & Wang et al. (2009) \\
\hline Initial reservoir pressure, $\mathrm{Pa}$ & $2.8 \mathrm{E}+07$ & $5.1 \mathrm{E}+07$ & $4.1 \mathrm{E}+07$ & Cramer (1986) \\
\hline Pay zone thickness, m & 7.62 & 22.86 & 12.19 & Cramer (1986) \\
\hline Total compressibility, $\mathrm{Pa}^{-1}$ & $2.9 \mathrm{E}-10$ & $1.2 \mathrm{E}-09$ & $9.8 \mathrm{E}-10$ & Dechongkit and Prasad (2011) \\
\hline Reservoir temperature, $\mathrm{K}$ & 352 & 400 & 389 & LeFever (2005) \\
\hline Oil API gravity, API & 39 & 45 & 42 & Breit et al. (1992) \\
\hline Reservoir permeability, $\mathrm{m}^{2}$ & $1.0 \mathrm{E}-19$ & $2.0 \mathrm{E}-17$ & $4.9 \mathrm{E}-18$ & Sarg (2012) \\
\hline$k_{\mathrm{v}} / k_{\mathrm{h}}$ & 0.001 & 1 & 0.1 & Pitman (2001) \\
\hline Reservoir porosity, \% & 2.0 & 10.0 & 5.0 & Sonnenberg (2011) \\
\hline Initial water saturation & 0.25 & 0.45 & 0.30 & Simenson (2010) \\
\hline
\end{tabular}

Table 2 Grid dimensions and volume calculations for the base reservoir model

\begin{tabular}{ll}
\hline Parameter & Value \\
\hline Length $L, \mathrm{~m}$ & 122 \\
Breadth $B, \mathrm{~m}$ & 305 \\
Thickness $h, \mathrm{~m}$ & 12.2 \\
Number of grid blocks in the $X$-, $Y$ - and $Z$-directions & $28,25,10$ \\
Grid dimensions in the $X$-, $Y$ - and $Z$-directions, $\mathrm{m}$ & $(\ldots) *, 12.2,1.22$. \\
Bulk reservoir volume at reservoir conditions, $\mathrm{m}^{3}$ & $4.5 \mathrm{E}+05$ \\
Total pore volume at reservoir conditions, $\mathrm{m}^{3}$ & $2.2 \mathrm{E}+04$ \\
Hydrocarbon pore volume at reservoir conditions, $\mathrm{m}^{3}$ & $1.5 \mathrm{E}+04$ \\
Original oil in place (OOIP) at surface conditions, $\mathrm{m}^{3}$ & $1.1 \mathrm{E}+04$ \\
Original gas in place (OGIP) at surface conditions, $\mathrm{m}^{3}$ & $2.6 \mathrm{E}+06$ \\
\hline
\end{tabular}

* $X$-direction has variable length due to local grid refinement various studies (Simenson 2010; LeFever 2011). The three integrated litho-facies were divided into 10 layers of the model (Table 7).
The Dykstra-Parsons coefficient (DPC) was used to quantify reservoir heterogeneity in the model. With the help of the Stanford Geostatistical Modeling Software (SGeMS), it was ensured that the generated permeability 
Table 3 Hydraulic fracture properties in the reservoir model (Kurtoglu 2014; Kumar et al. 2013)

\begin{tabular}{lll}
\hline Parameter & Injector fracture & Producer fracture \\
\hline Fracture width, $\mathrm{m}$ & 0.009 & 0.009 \\
Fracture half-length, $\mathrm{m}$ & 122 & 122 \\
Fracture height, $\mathrm{m}$ & 12.2 & 12.2 \\
Fracture permeability, $\mathrm{m}^{2}$ & $2.30 \mathrm{E}-13$ & $6.90 \mathrm{E}-14$ \\
Fracture conductivity, $\mathrm{m}^{3}$ & $2.02 \mathrm{E}-15$ & $6.02 \mathrm{E}-16$ \\
\hline
\end{tabular}

field results in a predetermined Dykstra-Parsons coefficient of 0.4. In other words, the reservoir permeability followed a normal distribution with a known standard variance of 0.5 . The mean permeability for each layer was known as displayed in Table 7. Heterogeneous permeability fields for these three pay zones were generated using sequential Gaussian simulation with an exponential variogram model, omnidirectional range of $45 \mathrm{~m}$, and the nugget effect was assumed zero.

\subsection{Modeling natural and induced fractures}

In reality, a significant amount of natural and induced fractures often exist within the stimulated reservoir volume and affect the fluid transport. In this work, we explicitly create two natural/induced fractures to investigate how they will change the flow pattern of injected $\mathrm{CO}_{2}$. Transmissibility of cells containing natural fractures should be different to the transmissibility of cells representing the matrix block (Sakhaee-Pour and Wheeler 2016). Figure 3 displays the perforation plane of the reservoir model containing natural and induced fracture networks. These two

Table 4 Compositional data of reservoir fluid (Nojabaei et al. 2013)

\begin{tabular}{lllllccc}
\hline Component & $\begin{array}{l}\text { Molar } \\
\text { fraction }\end{array}$ & $\begin{array}{l}\text { Critical pressure, } \\
\mathrm{Pa}\end{array}$ & $\begin{array}{l}\text { Critical } \\
\text { temperature, } \mathrm{K}\end{array}$ & $\begin{array}{l}\text { Acentric } \\
\text { factor }\end{array}$ & $\begin{array}{l}\text { Molar weight, } \\
\mathrm{g} / \mathrm{mol}\end{array}$ & $\begin{array}{l}\text { Critical volume, } \\
\mathrm{m}^{3} / \mathrm{mol}\end{array}$ & $\begin{array}{l}\text { Parachor } \\
\text { coefficient }\end{array}$ \\
\hline $\mathrm{CO}_{2}$ & 0.00000 & $7,352,800$ & 304 & 0.2250 & 44.01 & 0.000000207 \\
$\mathrm{C}_{1}$ & 0.36736 & $4,501,570$ & 186 & 0.0102 & 16.54 & 0.000098637 \\
$\mathrm{C}_{2}$ & 0.14885 & $4,962,130$ & 306 & 0.1028 & 30.43 & 0.000146082 \\
$\mathrm{C}_{3}$ & 0.09334 & $4,231,900$ & 370 & 0.1520 & 44.10 & 0.000202892 \\
$\mathrm{C}_{4}$ & 0.05751 & $3,755,180$ & 422 & 0.1894 & 58.12 & 0.00025658 \\
$\mathrm{C}_{5}-\mathrm{C}_{6}$ & 0.06406 & $3,170,390$ & 486 & 0.2684 & 78.30 & 0.000336489 \\
$\mathrm{C}_{7}-\mathrm{C}_{12}$ & 0.15854 & $2,496,720$ & 585 & 0.4291 & 120.56 & 0.000549993 \\
$\mathrm{C}_{13}-\mathrm{C}_{21}$ & 0.07330 & $1,714,980$ & 740 & 0.7203 & 220.72 & 0.000948286 \\
$\mathrm{C}_{22}-\mathrm{C}_{80}$ & 0.03704 & $1,306,940$ & 1025 & 1.0159 & 443.52 & 0.02502 \\
\hline
\end{tabular}

Table 5 Binary interaction parameters for the fluid component (Nojabaei et al. 2013)

Table 6 Well properties and operation restrictions used in the reservoir model (Kumar et al. 2013; Kurtoglu 2014; Shoaib and Hoffman 2009)

\begin{tabular}{llllllllll}
\hline Component & $\mathrm{CO}_{2}$ & $\mathrm{C}_{1}$ & $\mathrm{C}_{2}$ & $\mathrm{C}_{3}$ & $\mathrm{C}_{4}$ & $\mathrm{C}_{5}-\mathrm{C}_{6}$ & $\mathrm{C}_{7}-\mathrm{C}_{12}$ & $\mathrm{C}_{13}-\mathrm{C}_{21}$ & $\mathrm{C}_{22}-\mathrm{C}_{80}$ \\
\hline $\mathrm{CO}_{2}$ & Zero & 0.103 & 0.13 & 0.135 & 0 & 0 & 0 & 0 & 0 \\
$\mathrm{C}_{1}$ & 0.103 & Zero & 0.005 & 0.0035 & 0.0035 & 0.0037 & 0.003 & 0.0033 & 0.0033 \\
$\mathrm{C}_{2}$ & 0.13 & 0.005 & Zero & 0.0031 & 0.0031 & 0.0031 & 0.003 & 0.0026 & 0.0026 \\
$\mathrm{C}_{3}$ & 0.135 & 0.0035 & 0.0031 & Zero & 0 & 0 & 0 & 0 & 0 \\
$\mathrm{C}_{4}$ & 0 & 0.0035 & 0.0031 & 0 & Zero & 0 & 0 & 0 & 0 \\
$\mathrm{C}_{5}-\mathrm{C}_{6}$ & 0 & 0.0037 & 0.0031 & 0 & 0 & Zero & 0 & 0 & 0 \\
$\mathrm{C}_{7}-\mathrm{C}_{12}$ & 0 & 0.0033 & 0.0026 & 0 & 0 & 0 & Zero & 0 & 0 \\
$\mathrm{C}_{13}-\mathrm{C}_{21}$ & 0 & 0.0033 & 0.0026 & 0 & 0 & 0 & 0 & Zero & 0 \\
$\mathrm{C}_{22}-\mathrm{C}_{80}$ & 0 & 0.0033 & 0.0026 & 0 & 0 & 0 & 0 & 0 & Zero \\
\hline
\end{tabular}

\begin{tabular}{lll}
\hline Injector & Maximum rate, $\mathrm{m}^{3} /$ day & $2.8 \mathrm{E}+04$ \\
& Injection bottom-hole pressure, Pa & $6.9 \mathrm{E}+07$ \\
Producer & Maximum rate, $\mathrm{m}^{3} /$ day & 47.7 \\
& Production bottom-hole pressure, Pa & $3.5 \mathrm{E}+06$ \\
Simulation time, years & & 30 \\
\hline
\end{tabular}


Table 7 Heterogeneous thickness layer in reservoir model clubbed in 3 types to consider the 10 different lithology layers

\begin{tabular}{lllll}
\hline Layer & Facies & Pay zone thickness, $m$ & Generated permeability range, $\mathrm{m}^{2}$ & ${\text { Average permeability, } \mathrm{m}^{2}}^{2}$ \\
\hline $1-2$ & E1, F, D2 & 2.4 & $2.0 \mathrm{E}-19-6.4 \mathrm{E}-18$ & $2.0 \mathrm{E}-18$ \\
$3-6$ & C1, C2, D1 & 4.9 & $8.5 \mathrm{E}-19-2.3 \mathrm{E}-17$ & $8.9 \mathrm{E}-18$ \\
$7-10$ & A, B & 4.9 & $2.0 \mathrm{E}-19-9.3 \mathrm{E}-18$ & $3.9 \mathrm{E}-18$ \\
\hline
\end{tabular}
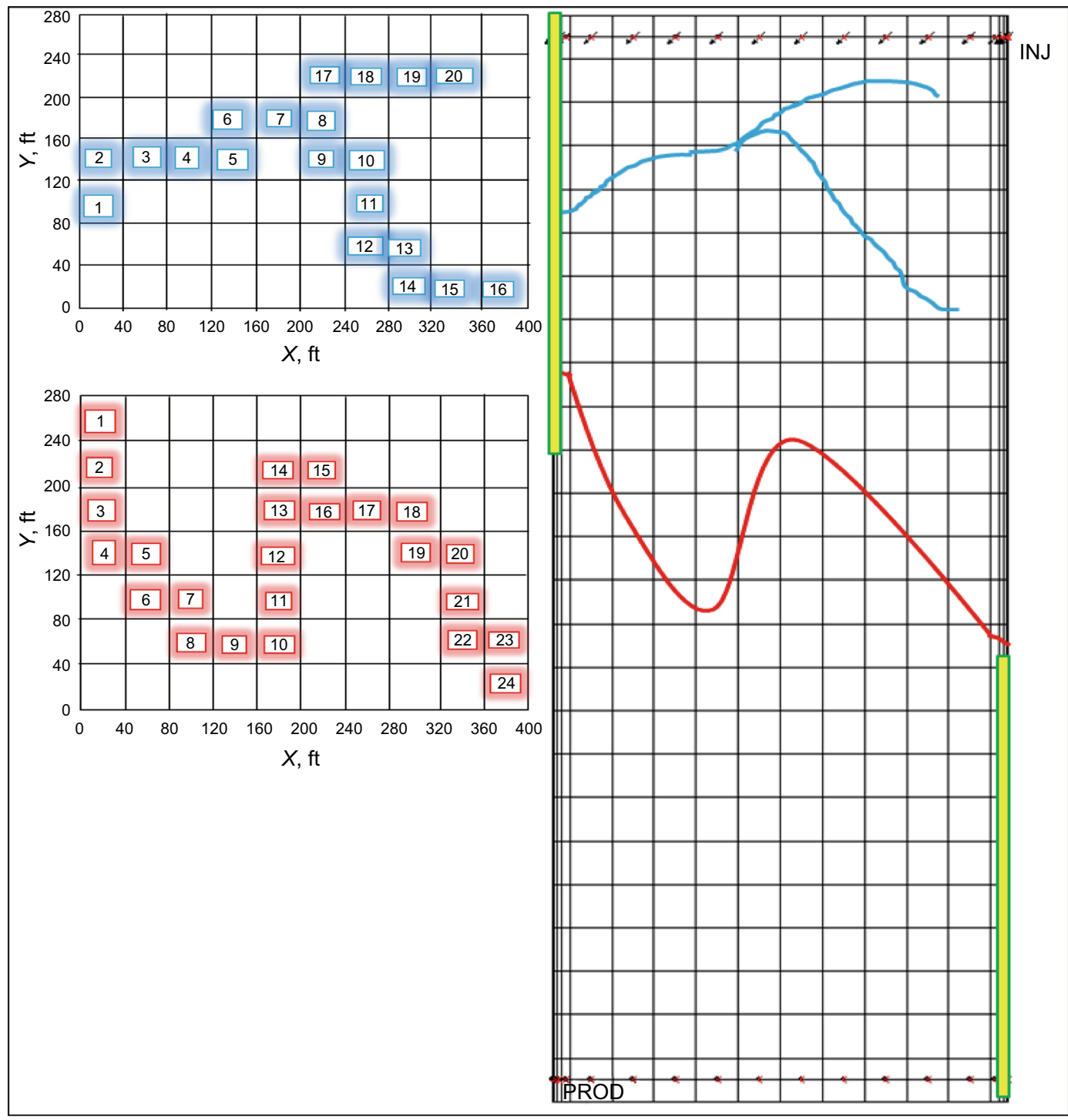

Fig. 3 Natural and induced fracture network simulated in the reservoir. The rectangles in yellow signify the hydraulic fracture length and location in the model (invisible due to local grid refinement). The fracture in red forms a connective path for fluids

fractures were implemented in the well perforation plane to account for the flow transport mechanism and better visualize the flow of injected $\mathrm{CO}_{2}$ into the reservoir. In Fig. 3, the numbered grid blocks are fracture cells. The calculated effective permeability of each fracture cell with respect to to travel between the hydraulic fractures corresponding to the injector and producer. The fracture in blue defines the extent of the reservoir

the governing dominant flow due to matrix-fracture and/or fracture-fracture interaction was two orders of magnitude larger than the permeability in matrix (Sakhaee-Pour and Wheeler 2016). 


\subsection{Modeling stress-dependent permeability}

A significant pressure change in the depletion process leads to major changes in the stress field of the formation. During production, induced stresses will alter the aperture and permeability of fractures. For example, the induced stresses can close the fracture openings, decrease the permeability and may significantly block mass transfer between the fracture and the matrix. During $\mathrm{CO}_{2}$ injection into the formation, stress changes may reactivate the natural fractures providing path for $\mathrm{CO}_{2}$ to migrate into the matrix displacing oil toward the well perforations. Hence, stressdependent permeability will play a critical role in designing the $\mathrm{CO}_{2}$ injection profile into a tight formation for enhanced oil recovery.

To evaluate the pressure-dependent permeability and porosity of the fractures, Kurtoglu (2014) carried out multistress permeability tests on three Middle Bakken core samples. Permeability was measured as a function of increasing effective stress. Their laboratory study of permeability variation with stress was employed in our reservoir simulation.

\section{Simulation results}

The simulation results focus on emphasizing the effect of shale formation properties on oil recovery and the amount of hydrocarbon pore volume of $\mathrm{CO}_{2}$ injected into the formation. An important caveat about the simulation results is that the base reservoir model focuses on a small segment of the original reservoir formation.

\subsection{Injector-producer pattern}

To understand the significance of $\mathrm{CO}_{2}$ injection, oil production in primary recovery is compared with oil production with $\mathrm{CO}_{2}$ injection in Fig. 4. Without $\mathrm{CO}_{2}$ injection, the total oil recovery was $7.4 \%$ after 30 years of production. It increased to $53 \%$ with continuous $\mathrm{CO}_{2}$ injection started from the beginning of production. Total $\mathrm{CO}_{2}$ injected was $113 \%$ hydrocarbon pore volume (HCPV). Oil recovery increases by injecting $\mathrm{CO}_{2}$ are also noted in other studies, as Pu and Hoffman (2014) reported an incremental oil recovery of $35 \%$ in the Middle Bakken with a 15 stage injection well and a nearby production well. As $\mathrm{CO}_{2}$ is injected through hydraulically fractured well perforations, it will rapidly flow through these fractures without permeating the rock matrix. Pressure differential due to $\mathrm{CO}_{2}$ injection into the formation will push $\mathrm{CO}_{2}$ to permeate within the rock. During this flow, $\mathrm{CO}_{2}$ could also displace oil deeper into the rock matrix. On the contrary, $\mathrm{CO}_{2}$ can also lead to oil swelling, and hence displacing more oil out

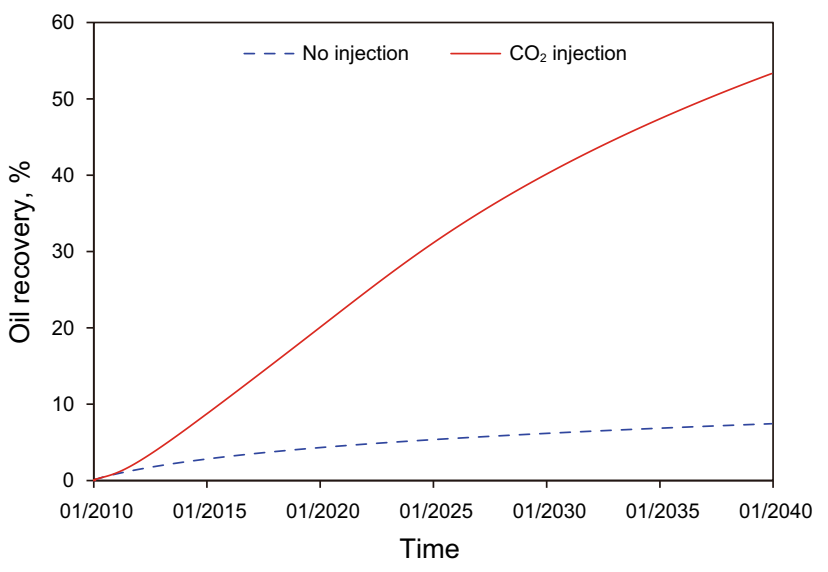

Fig. 4 Oil recovery comparison with and without $\mathrm{CO}_{2}$ injection at the end of simulation life

of the rock matrix. As $\mathrm{CO}_{2}$ continues to permeate within the rock matrix, oil will be displaced to migrate out of the rock surface and toward the fractures based on lower viscosity and oil swelling generated by $\mathrm{CO}_{2}$. As pressure is equalized throughout the low-permeability matrix, miscible phase of oil and $\mathrm{CO}_{2}$ will improve oil mobilization. Beyond this point, concentration gradient-driven diffusion will displace oil out of the rock matrix toward the fractures.

\subsection{Effect of simulated natural fractures}

Two connected natural fractures and induced fracture paths are simulated in the perforation plane. Figure 5 shows that $\mathrm{CO}_{2}$ injected in the hydraulic fracture in the top-left corner takes the flow path created by the high permeable induced and natural fractures in the formation. The presence of fractures dominates the flow mechanism in the reservoir. The comparison of three models (i.e., homogeneous, naturally fractured homogeneous and naturally fractured heterogeneous) is illustrated in Fig. 6.

The major impact of the presence of natural fractures in oil recovery is observed in Fig. 6. The homogeneous reservoir displayed maximum oil recovery for the same amount of $\mathrm{CO}_{2}$ injection. By comparing with the homogeneous model (i.e., represented by the blue curve), we notice that the existence of natural fractures in the homogeneous model increases the total oil recovery by $15 \%$ and it doubles the total injected volume of $\mathrm{CO}_{2}$ being injected. These two observations are clear indications of the importance of naturally fractured media in tight formations for $\mathrm{CO}_{2} \mathrm{EOR}$.

To study the $\mathrm{CO}_{2}$ storage in the formation, it is important to take into consideration the amount of $\mathrm{CO}_{2}$ being recycled. Figure 7 provides the mole fraction of $\mathrm{CO}_{2}$ observed in the production well along with hydrocarbon production as time progresses. Specifically, the natural 


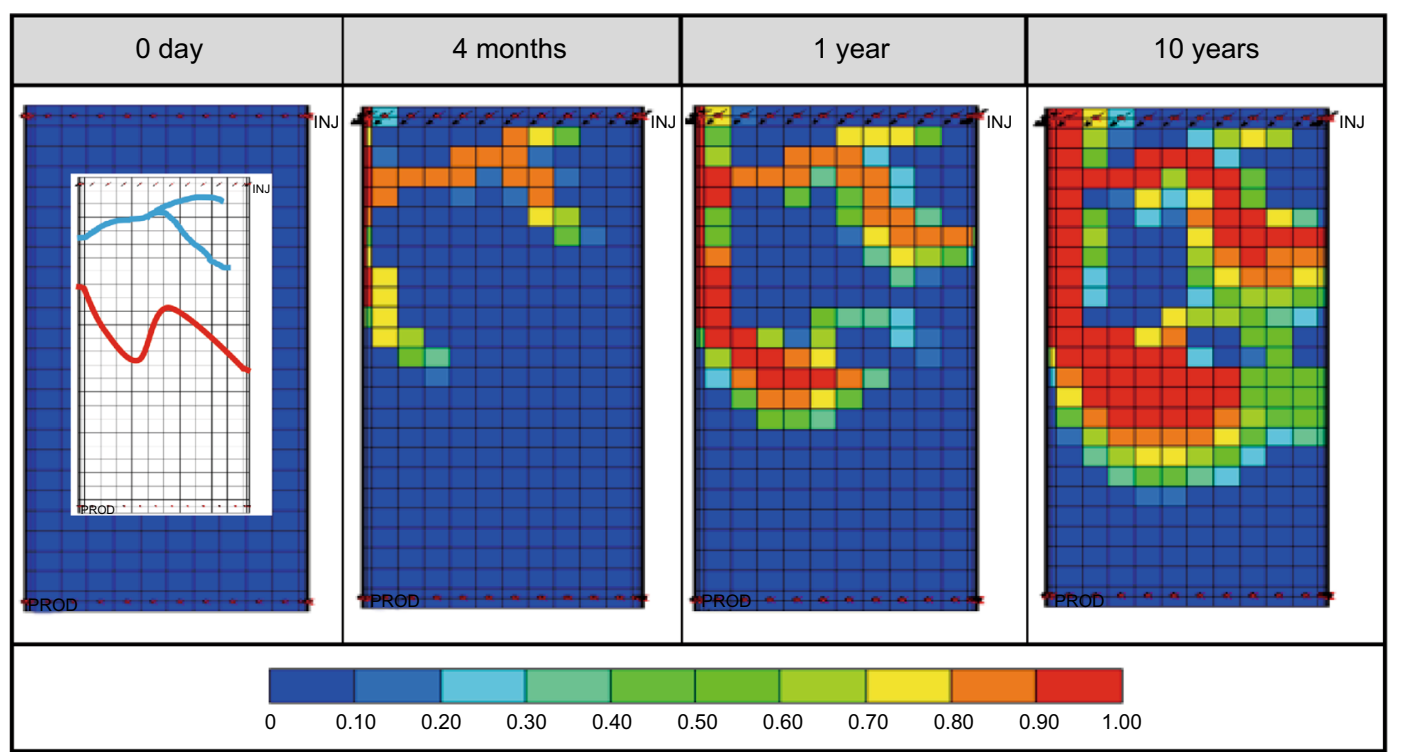

Fig. $5 \mathrm{CO}_{2}$ mol fraction profile with time progression in the perforation plane affected by the modeled natural fractures

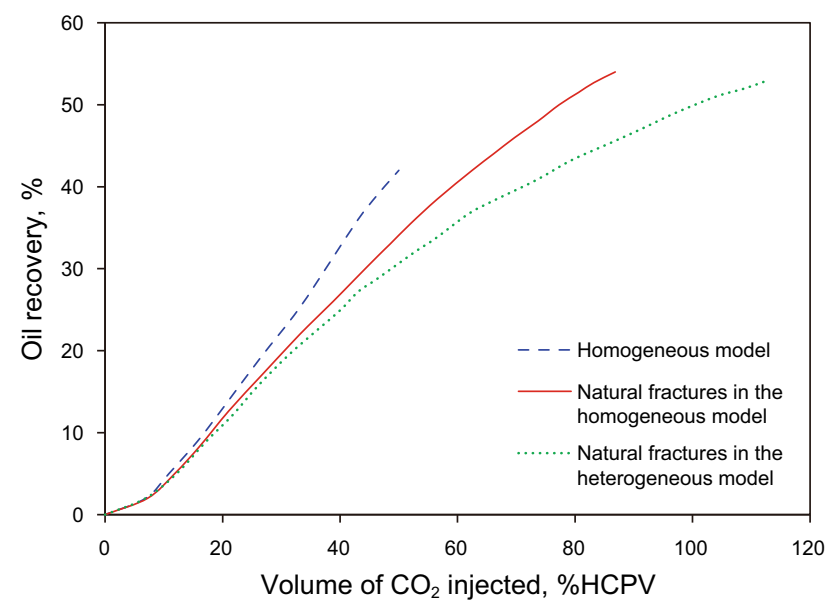

Fig. 6 Simulation results for 3 different reservoir models after 30 years of simulation life

fracture in red was built in the reservoir model to display the effect of connected induced and natural fractures during continuous injection and production. $\mathrm{No} \mathrm{CO}_{2}$ breakthrough takes place in the homogeneous model in the time of simulation. On the other hand, the existence of natural fractures provides a highway for injected $\mathrm{CO}_{2}$ to be quickly produced, resulting in a rapid $\mathrm{CO}_{2}$ breakthrough.

\subsection{Effect of stress-dependent permeability}

The study included three types of rock formations: (1) stiff rock type, (2) medium rock type and (3) soft rock type. Soft rock type means that the formation is highly stress sensitive and permeability variations will be significant based on the mean effective stress in each reservoir zone. Stiff rock

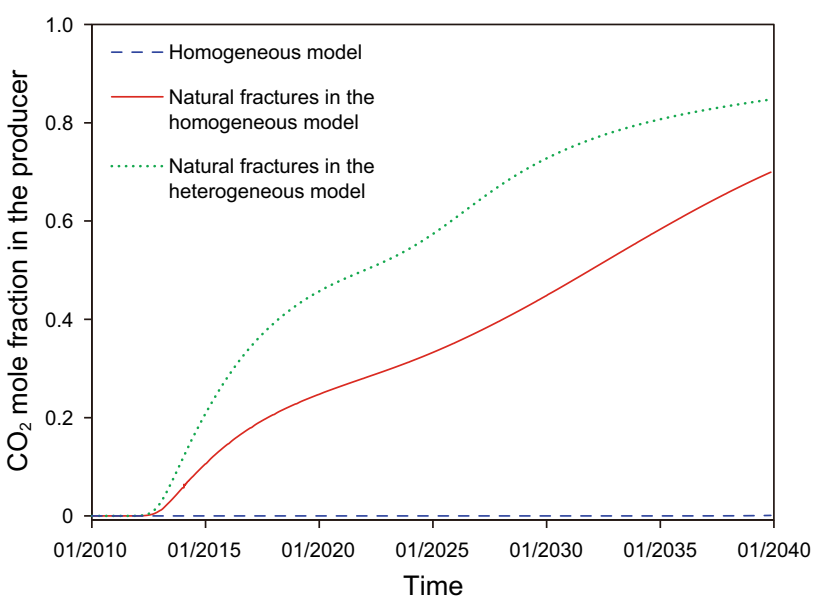

Fig. $7 \mathrm{CO}_{2}$ mol fraction in the production well for 3 different reservoir models with progression of simulation time

means that the formation is very tight and stress change does not strongly affect the permeability of the formation. Figure 8 defines the permeability multiplier for the soft, medium and stiff rock types. The permeability multiplier is defined as a ratio of current permeability to original permeability. Expansion curves define the increment in permeability with increasing mean effective stress, and compression curves define reduction in permeability with increasing mean effective stress in the reservoir zone.

The stress-dependent permeability will strongly affect the flow of $\mathrm{CO}_{2}$. Figure 9 compares the $\mathrm{CO}_{2}$ migration in the reservoir between stiff and soft rocks. In stiff rocks, $\mathrm{CO}_{2}$ virtually follows the path of natural and induced fractures. In soft rocks, permeability alterations after 


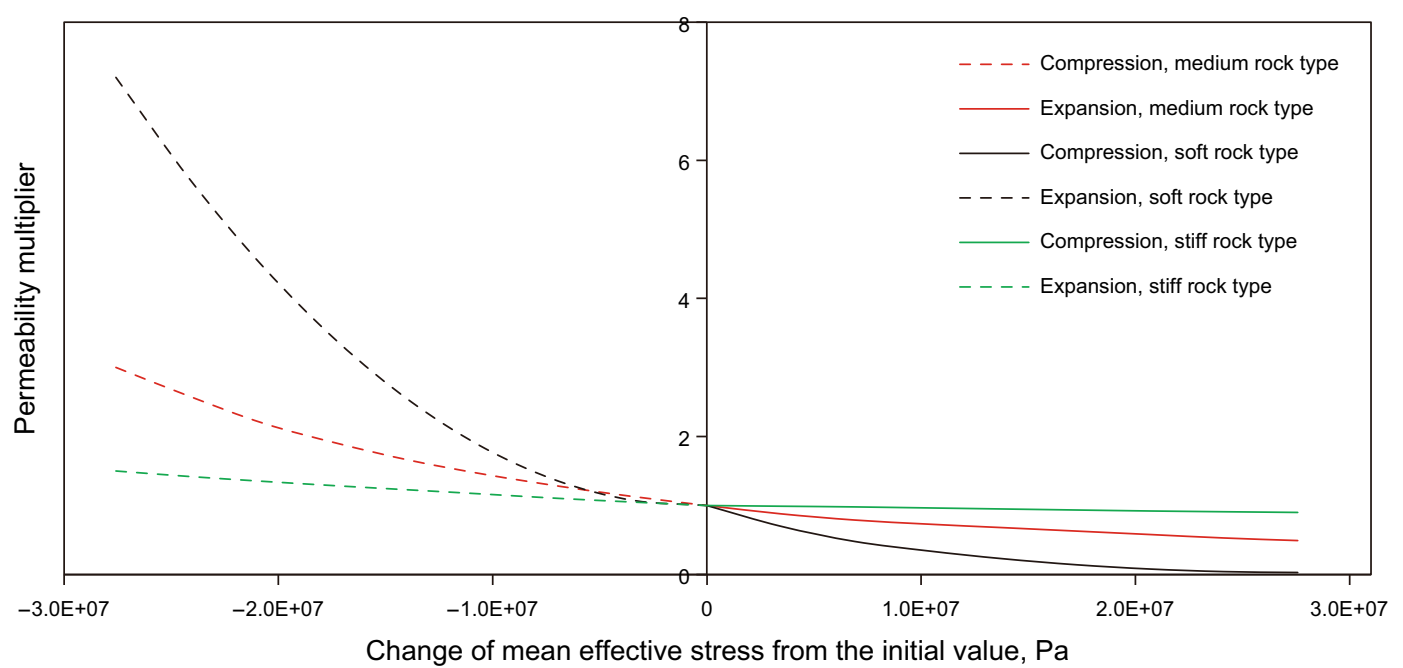

Fig. 8 Permeability multiplier for different rock types

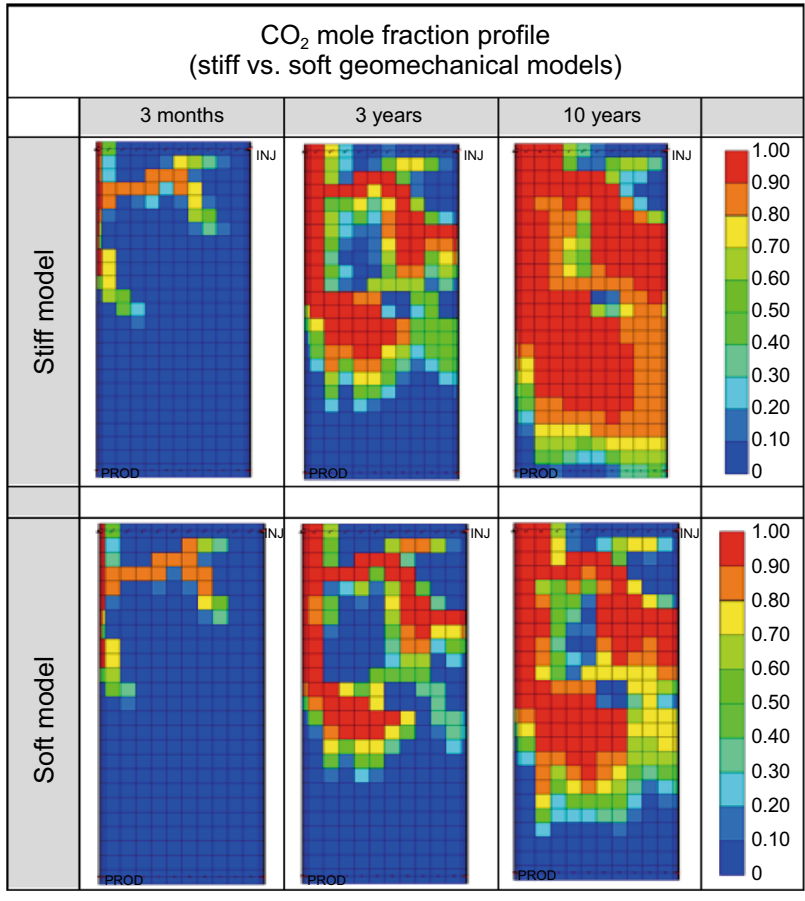

Fig. $9 \mathrm{CO}_{2}$ mol fraction profile for soft and stiff rock-type geomechanical models with time progression

10 years are very non-uniform in each zone. This defines the flow migration of reservoir fluids.

Figure 10 provides a comparison of oil recovery of different rock types. The highly stress-sensitive reservoir model has less oil recovery compared with other rock models. The main reason is the significant permeability change in the natural and induced fractures caused by depletion in the case of soft rock.

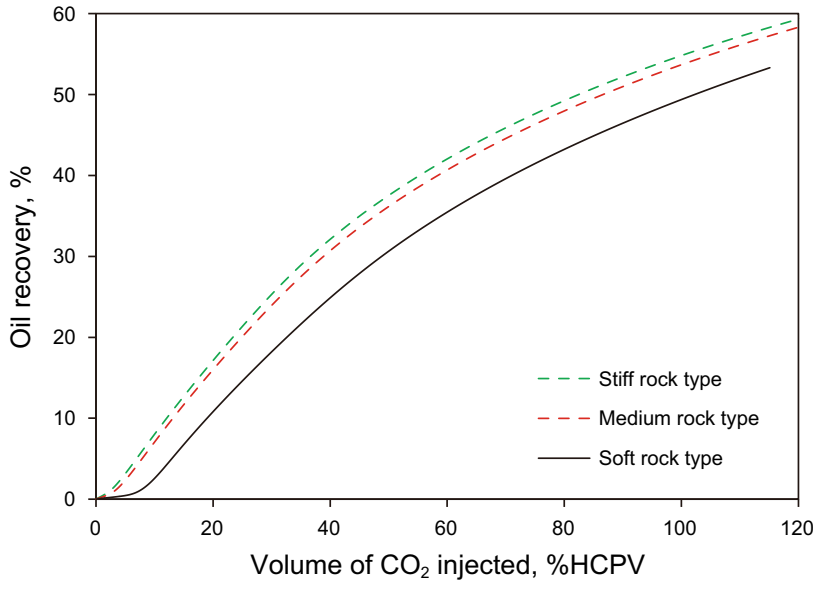

Fig. 10 Simulation results of oil recovery with amount of $\mathrm{CO}_{2}$ injected for different rock types

\subsection{Effect of fracture intersection}

Much evidence indicates that neighboring wells could be connected through hydraulic fractures (Mulkern et al. 2010). Therefore, it is critical to examine the efficiency of $\mathrm{CO}_{2}$ displacement in such situation. In this section, we created a model that has a hydraulic fracture that extends to connect both horizontal wells. The reservoir model was homogeneous without natural fractures for simplification. Figure 11 clearly shows that when the fracture connects both wells, the total injected volume of $\mathrm{CO}_{2}$ will significantly increase, while the oil recovery is reduced. The injected $\mathrm{CO}_{2}$ will find an easy path through the connected fracture to be produced. Such result indicates that the connection between two neighboring wells will impair the sweep efficiency of $\mathrm{CO}_{2}$, making it a bad candidate for $\mathrm{CO}_{2} \mathrm{EOR}$. 


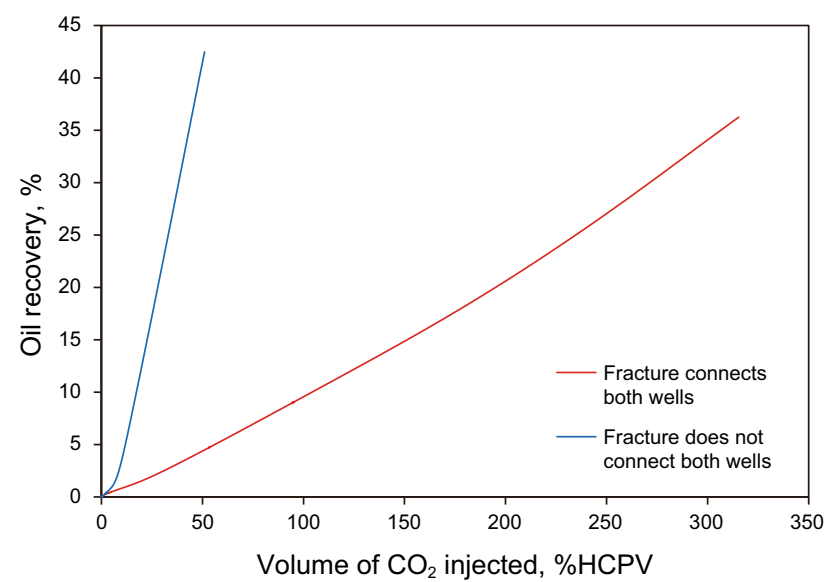

Fig. 11 Comparison between the cases with a fracture connects both wells and the case with a fracture does not connect both wells

\section{Response surface modeling (RSM) approach}

A RSM is defined as a proxy model developed by multiple regressions of all the uncertain parameters that affect the objective function. The response surface is a proxy for the reservoir simulator that allows fast estimation of the response.

\subsection{RSM workflow}

For this study, 9 parameters are used for both models to obtain a wider perspective of generating a proxy model. This allows us to observe the effect of each parameter, their interaction with other parameters and the ranking in which they affect the objective functions, i.e., oil recovery and $\mathrm{HCPV}$ of $\mathrm{CO}_{2}$ injected.

For this study, D-optimal design methodology is used to define the uncertainty between the parameters and to generate the number of simulation runs. This design will not only identify the key parameters, but will also consider the interaction effect and quadratic effect of parameters (Devegowda and Gao 2007).

D-optimal design is a 3-level experimental model, so it considers interactions and quadratic effects in the response surface. The model screens the less effective variables, combines the important parameters and selects the best outcome (Okenyi and Omeke 2012). D-optimal design minimizes the overall variance of the regression coefficients by maximizing the determinant. The number of simulation runs is higher when using this type of model and increases multiple folds with increasing number of factors. For $N$ number of factors, the total runs are:

Number of runs $=(N+1) *(N+2) / 2$

D-optimal model allows factors to have multiple levels. D-optimal design is a rigorous design based on quadratic regression. It includes square terms and linear terms. We enabled a Computer Modeling Group (CMG) workflow to use D-optimal design to implement response surface modeling, and the RSM polynomial fit will be of higher order, i.e., linear + quadratic + interaction parameters terms are used to generate a proxy model to validate the simulation results.

The workflow for the RSM is:

(1) Define the objective functions, i.e., oil recovery and $\mathrm{HCPV}$ of $\mathrm{CO}_{2}$ injected.

(2) Evaluate uncertainty factors and their distribution affecting the objective functions.

(3) Analyze the parameters (heavy hitters) that will highly influence the response of the optimizing parameter (one parameter at a time, OPAAT, analysis).

(4) Use design of experiments (D-optimal design) to generate simulation cases.

(5) Run numerical simulator for all simulation cases.

(6) Generate proxy model for each objective function.

For this study, it was desired to achieve a proxy model considering the effect of interaction parameters. An acceptable $R$-square of 0.85 is defined in the engine. Once the initial accuracy is achieved, more experiments are generated to achieve a higher $R$-square value. The RSM approach will first try to fit a linear relationship between the objective function and each critical parameter. If a parameter has a nonlinear relationship with the objective functions, a quadratic term $\left(x^{2}\right)$ will define the relation. If modifying 2 parameters at the same time has a stronger effect than the sum of their individual linear or quadratic effects, a cross-term $(x y)$ will define the relationship with the objective function.

It must be noted that the RSM approach only considers completion parameters to generate a proxy model. It means that only those parameters which are relevant to stimulation operations are considered for this study. Formation properties are not evaluated in this study as these properties cannot be changed and each reservoir has its characteristic set of defined formation and petrophysical properties. Therefore, the importance and usefulness of the proxy model is only after a reservoir model is built for the particular formation and then for operations. There is a need to carry out sensitivity analysis to have confidence in predicted recoveries from a formation. Stress-dependent permeability and adsorption properties defined for the base model are kept constant and not considered for the proxy model approach. Table 8 provides the variable range between maximum and minimum values for the uncertainty parameters used for generating a proxy model. 
Table 8 Uncertainty parameters with maximum, minimum and base values for the RSM approach

\begin{tabular}{|c|c|c|c|}
\hline Symbol & Minimum & Base case & Maximum \\
\hline Dist_Well, m & 152.4 & 304.8 & 457.2 \\
\hline Dist_Frac, m & 61.0 & 121.9 & 243.8 \\
\hline$K_{\mathrm{v}} / K_{\mathrm{h}}$ & 0.01 & 0.1 & 1.0 \\
\hline Prod_Perm, $\mathrm{m}^{2}$ & $9.9 \mathrm{E}-15$ & $6.9 \mathrm{E}-14$ & $1.5 \mathrm{E}-13$ \\
\hline Prod_HL, m & 61.0 & 121.9 & 182.9 \\
\hline Inj_Perm, m² & $6.9 \mathrm{E}-14$ & $2.3 E-13$ & $3.9 \mathrm{E}-13$ \\
\hline Inj_HL, m & 61.0 & 121.9 & 182.9 \\
\hline Inj_BHP, Pa & $4.8 \mathrm{E}+07$ & $6.9 \mathrm{E}+07$ & $7.6 \mathrm{E}+07$ \\
\hline Prod BHP, $\mathrm{Pa}$ & $1.4 \mathrm{E}+06$ & $3.4 \mathrm{E}+06$ & $6.9 \mathrm{E}+06$ \\
\hline
\end{tabular}

\subsection{Oil recovery: RSM}

The input is defined to produce a proxy model, which considers interaction and quadratic terms. The reduced quadratic model is utilized to create a tornado chart to indicate the significance of each uncertainty and also improve the proxy model. The polynomial fit consists of linear terms, quadratic terms and parameter interaction terms. Each term has its own statistical significance affecting the objective functions. The reduced quadratic model initially generates a proxy model consisting of all quadratic terms and interaction terms. The model then removes the statistically insignificant terms from the proxy equation. Figure 12 summarizes the effect estimate of uncertainty parameters on oil recovery generated by the RSM engine.

It can be observed that the RSM approach also follows a similar trend to that observed in OPAAT analysis. The result shows that the lateral distance between the injector and producer hydraulic fractures is the most critical parameter to optimize oil recovery in a $\mathrm{CO}_{2}$-EOR scenario. It is followed by the injection pressure and the distance between wells. Several interaction parameters have more critical effect on oil recovery than individual uncertainty. The significant advantage of the RSM approach over the OPAAT analysis is that the RSM has the ability to consider the effect of interaction and the quadratic effect of uncertainties, which is not achieved through the OPAAT. In addition, at reservoir scale, uncertainties among individual parameters simultaneously affect the flow modeling. In Fig. 12, 'Maximum' is the maximum value for the oil recovery among all simulation

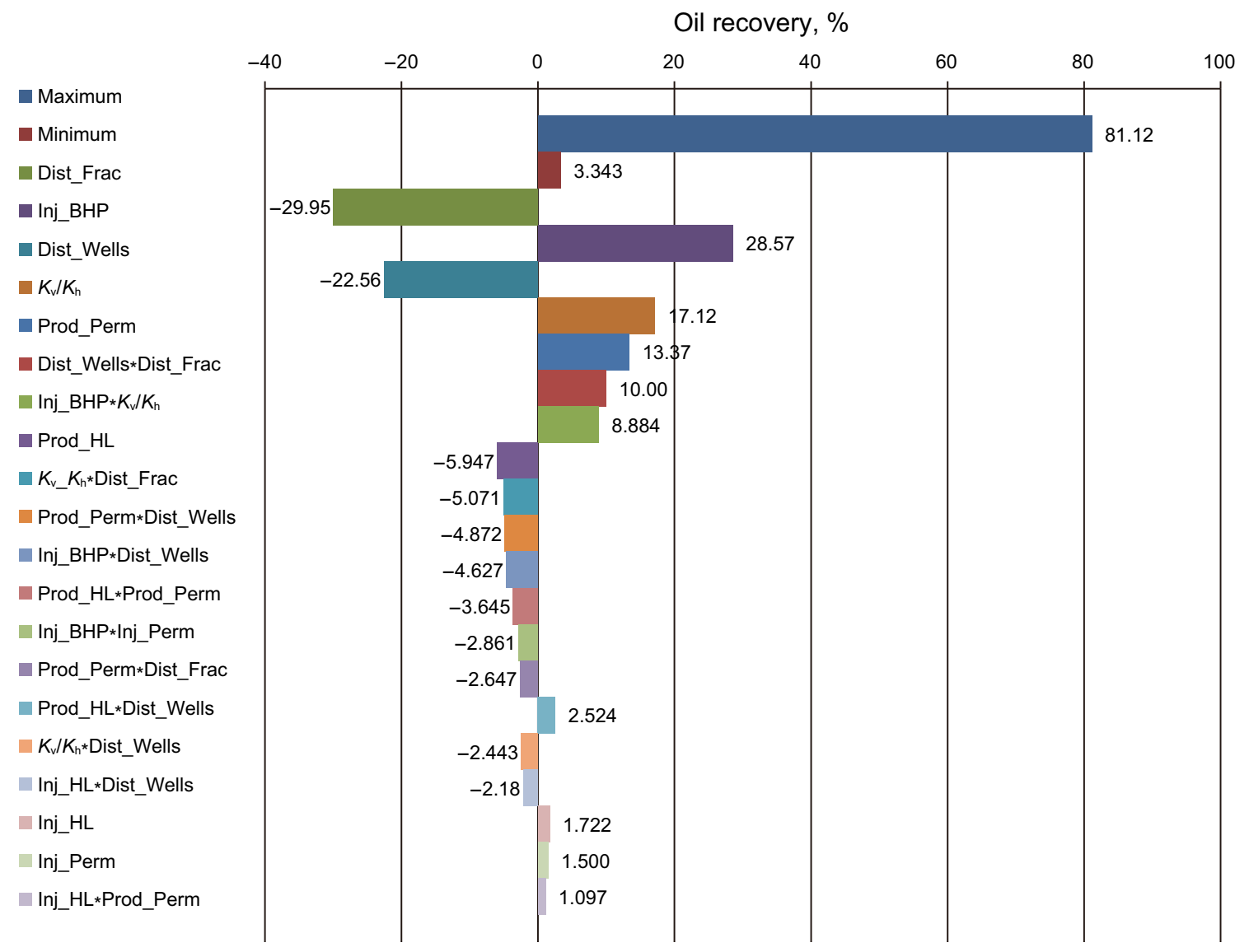

Fig. 12 Effect estimate of each uncertainty parameters and interaction of parameters on oil recovery (\%) 


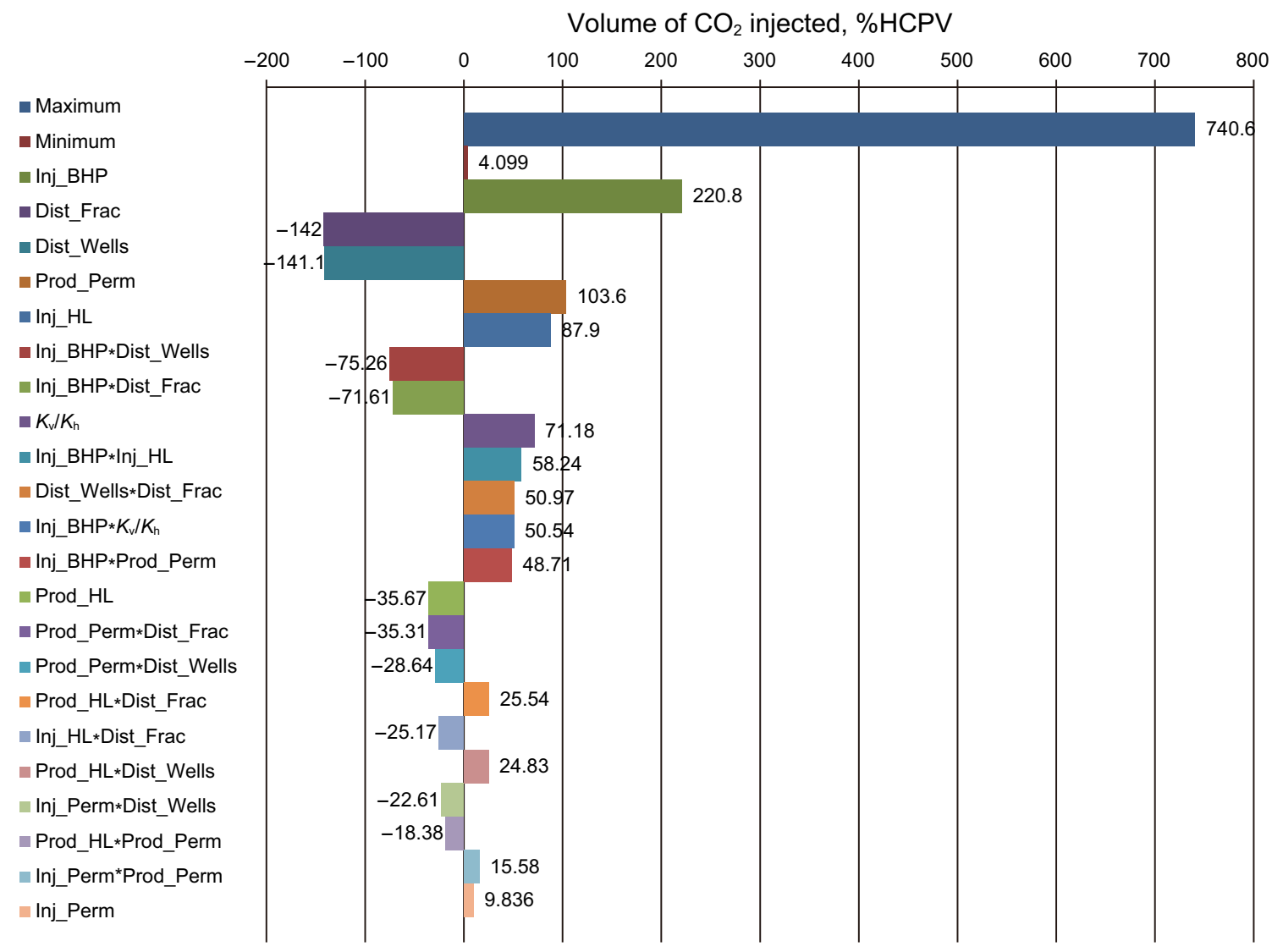

Fig. 13 Effect estimate of uncertainty parameters on $\mathrm{HCPV}$ of $\mathrm{CO}_{2}$ injected

runs, and similarly, 'Minimum' is the minimum oil recovery calculated among all simulation runs. After estimating the effect of uncertainties, the response surface model fits a proxy equation with critical parameters to estimate oil recovery factor without running simulations.

Equation (1) is the proxy equation as a function of uncertainty parameters analyzed by the RSM engine. The generated proxy equation is modeled with 20 uncertain terms. The equation is valid only for the Middle Bakken Formation.

$$
\begin{aligned}
& \text { \%Oil recovery }=6.49569+(1.67601 * \text { Inj_HL }) \\
& \quad-(0.573547 * \text { Prod_HL })+(0.00812039 * \\
& \text { Inj_BHP })-\left(7.27162 * K_{\mathrm{v}} / K_{\mathrm{h}}\right)+(0.256618 * \text { Prod_Perm }) \\
& \quad-(0.460401 * \text { Dist_Wells })-(1.00127 * \\
& \text { Dist_Frac })+(0.00841419 * \text { Prod_HL } * \text { Dist_Wells }) \\
& \quad-\left(0.0822629 * K_{\mathrm{v}} / K_{\mathrm{h}} * \text { Dist_Wells }\right)-(0.341462 * \\
& \left.K_{\mathrm{v}} / K_{\mathrm{h}} * \text { Dist_Frac }\right)+(0.0111152 * \text { Dist_Wells } * \text { Dist_Frac })
\end{aligned}
$$

\subsection{HCPV of $\mathrm{CO}_{2}$ injected: RSM}

$\mathrm{CO}_{2}$ injectivity is a critical consideration for $\mathrm{CO}_{2} \mathrm{EOR}$ as well as $\mathrm{CO}_{2}$ sequestration. Figure 13 illustrates the effect estimation of uncertainty parameters on hydrocarbon pore volume of $\mathrm{CO}_{2}$ injected. The result shows that the injection pressure is the most critical parameter for both HCPV of $\mathrm{CO}_{2}$ injected and oil recovery. It is followed by distance between fractures and distance between wells. It is also observed that the injection pressure is combined with several interaction parameters and the effect of these interaction parameters has both negative and positive effects on the amount of $\mathrm{CO}_{2}$ injected. Therefore, it can be concluded that it is critical to evaluate the effect of interaction parameters on the objective functions instead of relying on OPAAT single-parameter analysis.

The proxy equation generated for $\mathrm{HCPV}$ of $\mathrm{CO}_{2}$ injected by the RSM engine: 


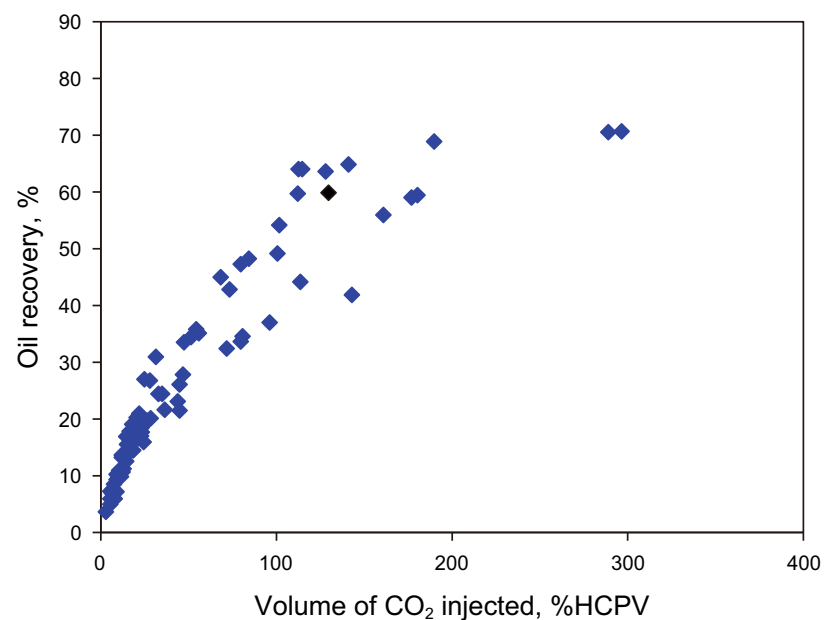

Fig. 14 Cross-plot of objective functions establishing a relation between the amounts of $\mathrm{CO}_{2}$ injected for every additional percentage of oil recovery

$$
\begin{aligned}
& \text { \% } \mathrm{HCPV} \text { of } \mathrm{CO}_{2} \text { injected }=-279.502 \\
& \quad+(0.070509 * \text { Inj _BHP })-\left(157.847 * K_{\mathrm{v}} / K_{\mathrm{h}}\right) \\
& \quad+(0.3192 * \text { Prod _Perm })+(1.34283 * \text { Dist _Wells }) \\
& \quad+(3.84585 * \text { Dist_Frac })-(0.0743607 * \\
& \text { Inj_HL } * \text { Dist_Wells })-(0.167783 * \text { Inj_HL } * \text { Dist_Frac }) \\
& \quad+(0.0827781 * \text { Prod_HL } * \text { Dist_Wells })+ \\
& (0.170256 * \text { Prod_HL } * \text { Dist_Frac })
\end{aligned}
$$

From the RSM approach, a wider perspective of the simulation results could be analyzed and the range of objective function with dependence on uncertainty could be easily predicted.

For final analysis, a cross-plot was generated from all experimental runs as shown in Fig. 14. The plot defines the $\mathrm{CO}_{2}$ utilization factor for improving oil recovery. In general, a $\mathrm{CO}_{2}$ utilization factor of 3:1 can be observed from this cross-plot. It signifies that every $3 \%$ hydrocarbon pore volume of $\mathrm{CO}_{2}$ injected into the Middle Bakken Formation can lead to an incremental oil recovery of $1 \%$.

\section{Conclusions}

The research concluded that facilitating oil recovery from tight oil reservoirs by $\mathrm{CO}_{2}$ injection could be greater than primary depletion depending on natural and induced fracture network connectivity. The presence of natural fractures significantly affects the flow migration of $\mathrm{CO}_{2}$ in the reservoir, directly impacting the sweep efficiency. Major conclusions of incorporating various physical processes into reservoir model are:
(1) Heterogeneity in the reservoir rock and permeability anisotropy are critical for unconventional tight oil formations and need to be considered in reservoir simulation studies. Reservoir heterogeneity and permeability anisotropy significantly affect the oil recovery as well as the $\mathrm{CO}_{2}$ breakthrough time in the production stream.

(2) Sensitivity analysis of the critical parameters with the OPAAT and RSM approaches provides significant understanding of critical parameters. The lateral distance between the injector hydraulic fracture and producer hydraulic fracture is the most critical parameters that affect oil recovery. Other critical factors are hydraulic fracture permeability of the production well and then the distance (acre spacing) between the injection and production wells. Natural fracture connectivity strongly influences the role of hydraulic fracture permeability and fracture halflength in the reservoir. These parameters become insignificant in the absence of natural and induced fractures in the formation.

(3) The RSM model estimated injection pressure as the most critical parameter for both the amount of $\mathrm{HCPV}$ of $\mathrm{CO}_{2}$ injected and the oil recovery. It is followed by the distance between fractures and the distance between wells. It was also noticed that when the injection pressure was combined with several interaction parameters, the effect of these interaction parameters had negative as well as positive effects on the amount of $\mathrm{CO}_{2}$ injected. It can hence be concluded that it is critical to evaluate the effect of interaction parameters on the objective functions instead of relying on the OPAAT single-parameter analysis.

(4) $\mathrm{A} \mathrm{CO}_{2}$ utilization factor of 3:1 was evaluated using the base reservoir model for improving oil recovery in the Middle Bakken Formation. It signifies that for every $3 \% \mathrm{HCPV}$ of $\mathrm{CO}_{2}$ injected into the formation, an incremental oil recovery of $1 \%$ could be achieved.

Acknowledgements The authors greatly appreciate the support from the Computer Modeling Group Ltd. for providing the simulation software, and the support from the Warwick Energy Group and University of Oklahoma to publish this work.

Open Access This article is distributed under the terms of the Creative Commons Attribution 4.0 International License (http://crea tivecommons.org/licenses/by/4.0/), which permits unrestricted use, distribution, and reproduction in any medium, provided you give appropriate credit to the original author(s) and the source, provide a link to the Creative Commons license, and indicate if changes were made. 


\section{References}

Augus S, Armstrong B, de Reuck KM. International thermodynamic tables of the fluid state: carbon dioxide, vol. 3. Headington Hill Hall: Pergamon Press; 1973.

Breit VS, Stright Jr DH, Dozzo JA. Reservoir characterization of the Bakken shale from modeling of horizontal well production interference data. In: SPE rocky mountain regional meeting, May 18-21 May. Wyoming: Casper; 1992. doi: 10.2118/24320MS.

Cramer DD. Reservoir characteristics and stimulation techniques in the Bakken Formation and adjacent beds billings nose area Williston Basin. In: SPE rocky mountain regional meeting, May 19-21. Billings, Montana; 1986. doi: 10.2118/15166-MS.

Dechongkit P, Prasad M. Recovery factor and reserves estimation in the Bakken petroleum system (Analysis of the Antelope, Sanish and Parshall fields). In: Canadian unconventional resources conference, November 15-17. Alberta, Canada; 2011. doi:10. 2118/149471-MS.

Devegowda D, Gao H. Integrated uncertainty assessment for unconventional gas reservoir project development. In: SPE Eastern regional meeting, October 17-19, Lexington, Kentucky USA; 2007. doi:10.2118/111203-MS.

Hoffman BT, John GE. Improved oil recovery IOR pilot projects in the Bakken Formation. In: SPE low permeability symposium, May 5-6, Denver, Colorado; 2016. doi:10.2118/180270-MS.

Kalra S, Wu X. $\mathrm{CO}_{2}$ injection for enhanced gas recovery. In: SPE Western North American and rocky mountain joint meeting, April 17-18, Denver, Colorado; 2014. doi:10.2118/169578-MS.

Kumar S, Hoffman T, Prasad M. Upper and Lower Bakken Shale production contribution to the Middle Bakken reservoir. In: Unconventional resources technology conference, Denver, Colorado; 2013. doi:10.1190/urtec2013-001.

Kurtoglu B. Integrated reservoir characterization and modeling in support of enhanced oil recovery for Bakken. Ph.D. thesis. Colorado School of Mines, Golden, Colorado. 2014.

LeFever JA. Oil production from the Bakken Formation: a short history. North Dak Geol Surv Newsl. 2005;32(1):5-10.

LeFever JA. Horizontal drilling in the Williston Basin, United States and Canada. In: The Bakken-three forks petroleum system in the Williston Basin. Rocky Mountain Association of Geologists. 2011. pp. 508-29.

Mulkern ME, Asadi M, McCallun S. Fracture extent and zonal communication evaluation using chemical gas tracers. In: SPE eastern regional meeting, October 13-15, Morgantown, West Virginia, US. 2010. doi:10.2118/138877-MS

Nojabaei B, Johns RT, Chu L. Effect of capillary pressure on fluid density and phase behavior in tight rocks and shales. SPE Reserv Eval Eng. 2013;16(3):281-9. doi:10.2118/159258-PA.
Okenyi KC, Omeke JE. Well performance optimization using experimental design approach. In: SPE Nigeria annual international conference and exhibition, August 6-8, Lagos, Nigeria. 2012. doi:10.2118/162973-MS.

Pitman JK, Price LC, LeFever JA. Diagenesis and fracture development in the Bakken Formation, Williston Basin: implications for reservoir quality in the middle Member, US Department of the Interior, US Geological Survey (Reprint). 2001.

$\mathrm{Pu}$ W, Hoffman TB. EOS modeling and reservoir simulation study of Bakken gas injection improved oil recovery in the Elm Coulee Field, Montana. In: SPE/AAPG/SEG unconventional resources technology conference, August 25-27, Denver, Colorado, USA, 2014. doi:10.15530/urtec-2014-1922538.

Sakhaee-Pour A, Wheeler MF. Effective flow properties for cells containing fractures of arbitrary geometry. SPE J. 2016;21(3):965-80. doi:10.2118/167183-PA.

Sarg F. The Bakken-an unconventional petroleum and reservoir system. Golden: Colorado School of Mines; 2012.

Shen T, Moghanloo RG, Tian W. Ultimate $\mathrm{CO}_{2}$ storage capacity of an over-pressurized 2D aquifer model. In: EUROPEC, June 1-4, Madrid, Spain, 2015. doi:10.2118/174379-MS.

Shoaib S, Hoffman BT. $\mathrm{CO}_{2}$ flooding the Elm Coulee field. In: SPE rocky mountain petroleum technology conference, April 14-16, Denver, Colorado. 2009. doi:10.2118/123176-MS.

Simenson A. Depositional facies and petrophysical analysis of the Bakken Formation, Parshall Field, Mountrail County, North Dakota. MS thesis. Colorado School of Mines, Golden, Colorado. 2010.

Sonnenberg SA. TOC and pyrolysis data for the Bakken Shales, Williston Basin, North Dakota and Montana. In: The Bakkenthree forks petroleum system in the Williston Basin. 2011; pp.308-331.

Sorensen JA, Schmidt DD, Smith SA et al. Plains $\mathrm{CO}_{2}$ reduction (PCOR) partnership (phase II)-Williston Basin Field demonstration, Northwest McGregor $\mathrm{CO}_{2}$ huff ' $\mathrm{n}$ ' puff-regional technology implementation plan (RTIP). Energy and Environmental Research Center (Task 2). 2009. Topical report for the US Department of Energy 50 (2009).

Wang R, Zhao R, Yan P, et al. Effect of stress sensitivity on displacement efficiency in $\mathrm{CO}_{2}$ flooding for fractured low permeability reservoirs. Pet Sci. 2009;6(3):277-83. doi:10. 1007/s12182-009-0044-6.

Wang S, Kadhum M, Yuan Q, et al. Carbon dioxide in situ generation for enhanced oil recovery. In: Carbon management technology conference, July 17-20, Houston, Texas; 2017. doi:10.7122/ 486365-MS. 